\title{
CIDADES E PERIFERIAS NO MUNDO ANTIGO.
}

\section{Maria Beatriz Borba Florenzano ${ }^{1}$}

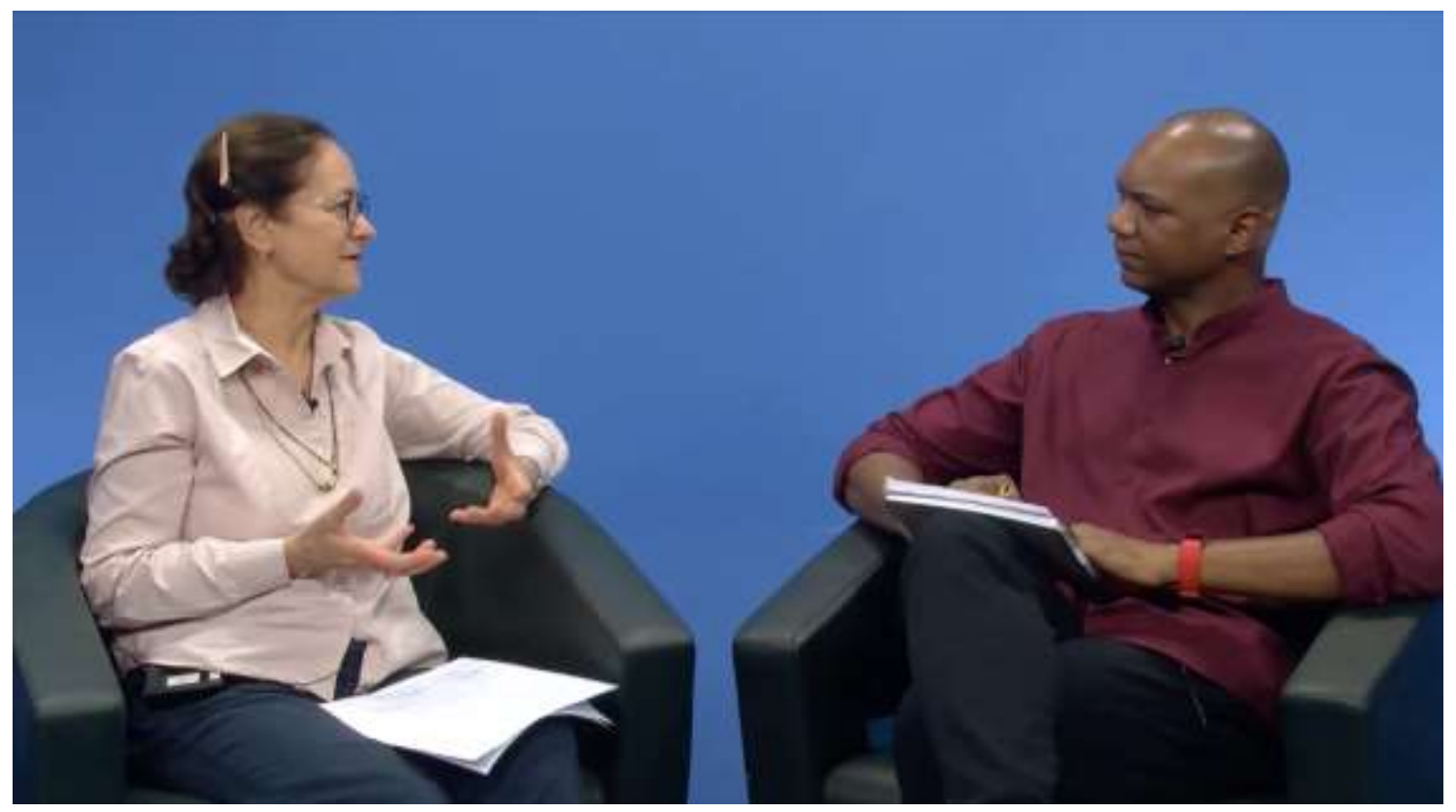

Entrevista nos estúdios da UNIFESP em 03 de setembro de 2018: Professora Maria B. B. Florenzano (USP) e Professor Gilberto da S. Francisco (UNIFESP). ${ }^{2}$

hiperlink para a entrevista https://youtu.be/KzAv8dfqGQc

Heródoto (Gilberto da Silva Francisco): Olá. Meu nome é Gilberto da Silva Francisco, eu sou professor de História Antiga do Departamento de História da Escola de Filosofia, Letras e Ciências Humanas da Universidade Federal de São Paulo. E hoje o tema da nossa entrevista da Revista Heródoto é a cidade antiga. Eu tenho o grande prazer de apresentar a professora Maria Beatriz Borba Florenzano, do Museu de Arqueologia e Etnologia da Universidade de São Paulo (MAE-USP). A

\footnotetext{
1 Professora Titular - Universidade de São Paulo, São Paulo, Brasil. E-mail: florenza@usp.br

${ }^{2}$ A equipe de alunos responsável pela transcrição e revisão desta entrevista foi composta por Renata Villela, Tairini Aparício de Almeida, Vitória Farias, Giula Cristiano, Jessica Laila Alves dos Santos, Júlio Cesar Aquino Teles Ferreira, Luana Alves da Silva, Lucas Arantes Lorga, Lucas Knabben e Maria Lidia de Almeida Ferreira Mota. Os trabalhos de transcrição e revisão da entrevista foram coordenados pelo professor Gilberto da Silva Francisco.
} 
professora Maria Beatriz é professora titular em Arqueologia pelo MAEUSP e é coordenadora geral do LABECA (Laboratório de Estudos sobre a Cidade Antiga). Professora, inicialmente, eu gostaria de agradecer a presença da senhora, o que é muito importante para a nossa revista.

Maria Beatriz Borba Florenzano: Eu que agradeço a oportunidade, Gilberto.

Heródoto: Eu gostaria de perguntar, inicialmente, sobre sua trajetória. A senhora é conhecida pela pesquisa numismática no Brasil, a pesquisa das moedas. Como foi essa transição entre a moeda e a cidade como objeto de estudo?

Florenzano: De fato toda a minha formação foi feita na área de Numismática, que é o estudo desses objetos pequeninos, redondos, que os gregos inventaram. Conhecemos essa história da invenção e da propagação da moeda entre os gregos. Depois, os romanos a adotaram e, até hoje, não sei por quanto tempo mais, temos ainda as moedas redondinhas de metal com figurinhas, imagens de um lado e do outro. Toda a minha formação, mestrado, doutorado, muitas pesquisas que realizei, foram pesquisas feitas sobre a iconografia monetária, a noção de valor e a circulação monetária.

Não é um campo de pesquisa que eu tenha abandonado, Gilberto. Eu continuei. Até este ano mesmo, 2018, publiquei um artigo. Aliás, é um capítulo de livro, sobre a iconografia monetária, está num livro chamado Typoi. ${ }^{3}$ Então não é um campo que eu tenha abandonado, ao contrário, agora que eu me aproximo do final da minha carreira, é um campo que pretendo retomar com alguma força, espero. Mas, o que eu percebi, é que para estudar a moeda, que é aquele objeto tão pequenino, tão miudinho, você precisa ter temperamento, e muitos dos alunos que chegavam até nós não tinham esse temperamento de ficar debruçado em cima daquelas pecinhas, classificando aquela porção de moedinhas, iguais ou parecidas; e muitos, inclusive, chegaram a abandonar o mestrado ou pediam um outro tema que não fosse o das moedas.

Quando fui convidada pelo professor Francisco Marshall da Universidade Federal do Rio Grande do Sul, em Porto Alegre, para participar de um projeto em Israel, que foi o projeto Apolônia, que você deve lembrar, tive um insight que me levou a refletir sobre a questão do espaço, pois esse

\footnotetext{
${ }^{3}$ Maria B. B. Florenzano. In God we trust: gods and god-like entities on ancient Greek coins (Plate XII). In: TYPOI. Greek and Roman coins seen through their images noble issuers, humble users? Proceedings of the International Conference Organized by the Belgian and French Schools at Athens, 26-28 September 2012. Liège: Presses Universitaires de Liège.
} 
projeto era justamente sobre o disciplinamento do espaço em Apolônia. Então, entrei de cabeça nos estudos sobre a paisagem e o espaço. Esse projeto sobre Apolônia deu certo até um certo ponto porque a área em Israel é muito instável para você participar efetivamente com financiamento brasileiro. Para a expedição de que participei, em 2000, obtive o apoio da FAPESP:4 éramos em cinco pessoas e pudemos pagar os trabalhadores e para comprar muitos livros e participar efetivamente do projeto. Publicamos alguns artigos sobre isso, e o professor Marshall ainda continuou por mais alguns anos.

Mas, a partir desse insight de que falei, me propus a preparar um projeto para estudar o espaço na Grécia Antiga; pensei em oferecer uma contribuição maior para a área da Arqueologia Clássica no Brasil. Como eu, você também foi aluno da professora Haiganuch Sarian, ${ }^{5}$ que foi uma batalhadora por essa área em nosso país, abrindo portas para muitos estudantes; para mim, para você, e para tantos outros alunos, sempre tentando valorizar a Arqueologia Clássica no Brasil. E eu sempre tive isso muito presente.

A partir do projeto Apolônia, pensei que o estudo do espaço poderia abrigar mais alunos e mais pesquisadores em todos os níveis. Por que o espaço é uma coisa muito grande e a organização do espaço entre os gregos, que era a nossa área de pesquisa, abre caminhos para pesquisas sobre religião, sobre as relações sociais, sobre a economia, sobre a produção artesanal, sobre tantos temas. E a partir disso, em 2004, montamos um grupo de estudos alunos e colaboradores e passamos um ano lendo os textos sobre cidade, sobre a metodologia de abordagem das cidades, sobre urbanismo, sobre paisagem. Começamos do princípio, lendo autores do século XIX como Fustel de Coulanges e do início e meados do XX como Max Weber e Gordon Childe. Desde as interpretações sobre a origem da cidade até a organização do espaço da pólis.

E, foi isso que nos permitiu, em 2005, elaborar um projeto e submeter à FAPESP que nos deu apoio por 10 anos e, agora, por mais dois anos, a FAPESP continua nos apoiando. Então, foi isso que nos permitiu criar esse laboratório, o Labeca. Eu acho que deu certo, porque a lista das pesquisas que foram envolvidas no interior desse laboratório, inclui 72 ou 73 títulos nos dez anos, entre iniciações científicas, mestrados, doutorados, pósdoutorados. Parece-me que deu certo e continua dando! Recebemos mensagens do Brasil todo, e também do exterior pedindo acesso aos Bancos de dados, à biblioteca e assim por diante. Acredito que tenha sido

\footnotetext{
${ }^{4}$ Fundação de Amparo à Pesquisa do Estado de São Paulo.

${ }^{5}$ Haiganuch Sarian, Professora Titular (aposentada), MAE-USP.
} 
um passo a mais no sentido da consolidação da nossa área de estudos de Arqueologia do Mediterrâneo Antigo. Agora vocês, jovens, vão fazer o resto.

Heródoto: Parece-me algo importante, a apresentação, a divulgação dos laboratórios, porque tem muita gente que não conhece os projetos de História Antiga e tem muita gente trabalhando. Nesse sentido, eu pediria para a senhora falar um pouco sobre a história do laboratório, quais são as questões agora que estão sendo discutidas e quem trabalha lá.

Florenzano: Como disse, a estruturação do Labeca começou com essa discussão em 2004, com a leitura e o debate sobre textos fundamentais a respeito da cidade. Nós montamos um primeiro projeto em 2005 (na verdade, propus ao MAE-USP, àquele momento, a criação de Laboratórios temáticos de pesquisa), e este projeto informou a criação do primeiro laboratório temático do Museu, voltado para uma pesquisa com um tema específico, que é a cidade antiga. No nosso caso, logo percebemos que não íamos conseguir trabalhar com a cidade romana; então, nos restringimos à cidade grega.

Esse laboratório foi criado como um campo para o debate, para o diálogo, para a discussão, e foram acolhidas pessoas que trabalhavam também com as cidades, mas em outras áreas: por exemplo, a Cibele Aldrovandi trabalhou com cidades helenísticas na Índia e trouxe sua contribuição. Como a professora Kormikiari, 6 que trabalha com as cidades púnicas, que são áreas de contato com os gregos. Então, fomos juntando as partes e foi criado esse espaço de diálogo. O MAE nos acolheu e sou muito orgulhosa de dizer que, depois, muitos outros laboratórios temáticos foram criados dentro do MAE, na área de Arqueologia Brasileira, na área de Etnologia e de Museologia também. Hoje, a pesquisa do MAE funciona baseada em laboratórios temáticos regimentais, com estatuto interno, com membros específicos nos vários níveis de formação, e assim por diante.

O Labeca foi criado nesse contexto e animado por esse primeiro projeto que previa uma série de linhas de pesquisa: espaço e sociedade, espaço e religião, espaço e política, espaço e produção, economia, circulação de bens e mercadorias etc. Isso tudo está no site, ${ }^{7}$ que com bastante dificuldade temos mantido. Sabemos que as universidades públicas vêm sofrendo cortes, mastemos conseguido manter um site em que colocamos nossas

\footnotetext{
${ }^{6}$ Maria Cristina Nicolau Kormikiari Passos, Professora Doutora, MAE-USP e cocoordenadora do Labeca.

${ }^{7}$ http://lwww.labeca.mae.usp.br
} 
notícias, a nossa produção científica, os nossos produtos educacionais; também aparece lá a equipe de pesquisadores e de estagiários.

Funcionamos durante algum tempo com bolsistas FAPESP, em uma época em que também a FAPESP tinha acesso a mais recursos. Houve épocas que chegamos a ter sete bolsistas-FAPESP, bolsistas de treinamento técnico trabalhando dentro do Labeca, isto nos cinco primeiros anos. Depois, nós conseguimos só dois bolsistas e hoje não temos nenhum bolsista de treinamento técnico. Em compensação, temos conseguido bolsistas da Universidade dentro do programa de permanência de estudantes que são bolsistas de graduação, que participam do Programa Unificado de Bolsas da USP e que nos têm ajudado muito. Temos também os bolsistas de iniciação científica, sobretudo com bolsa CNPq/PIBIC; e os outros bolsistas de mestrado e doutorado que apoiam o Labeca.

O Labeca tem um pequeno espaço de aproximadamente quinze metros quadrados que com recursos da FAPESP conseguimos mobiliar e equipar. Com minha bolsa de produtividade do CNPq procuro manter a biblioteca viva, centrada nos temas que nós estudamos. E, nesses dez anos, nós já organizamos um simpósio nacional e um simpósio internacional. Estamos organizando um segundo simpósio internacional agendado para abril do ano que vem (2019) e mantivemos ciclos de seminários internos. Chegamos até o décimo segundo ciclo. Nos ciclos de seminários, os pesquisadores apresentam as suas pesquisas para serem debatidas: muitos dos textos que eu publiquei e que ainda vou publicar foram debatidos antes nos seminários internos. Muitos dos ciclos também se debruçaram sobre o debate de textos importantes para o prosseguimento da pesquisa no Laboratório. E também foram apresentados estudos de pessoas de fora que posteriormente foram publicados. Da mesma forma, tivemos a oportunidades de promover disciplinas de extensão universitária.

Assim, vamos funcionando, com o objetivo de focalizar um tema. A minha ideia é que a dispersão não produz conhecimento, não inova o conhecimento. Mas, uma coisa que eu aprendi no Labeca, é que trabalhar em equipe é muito difícil. É muito mais fácil você ficar na sua sala, lendo e escrevendo e dando suas aulas. Trabalhar em equipe é difícil, mas o resultado para mim é muito gratificante.

A professora Elaine ${ }^{9}$, que faz parte do laboratório, também organizou uma exposição, e o Laboratório e os alunos envolvidos muito cresceram com

${ }^{8}$ Programa Institucional de Bolsas de Iniciação Científica do Conselho Nacional de Desenvolvimento Científico e Tecnológico (CNPq).

${ }^{9}$ Profa. Dra. Elaine Farias Veloso Hirata. Professora livre-docente do MAE-USP e cocoordenadora do Labeca desde o início. 
esse trabalho. Também ganhamos muito em conhecimento e experiência elaborando maquetes físicas e digitais, trabalhando com a divulgação científica, que sempre envolve muita pesquisa. E tudo isso só se consegue fazer com apoio de uma equipe. E é esta a maneira de funcionamento do Labeca. Publicamos também três livros, temos um outro no prelo pela editora Intermeios, em que há um capítulo em que se fala um pouco a história do Labeca. Até o final do ano, devemos terminar a produção de um quinto livro. Já temos os artigos, que junto com a Profa. Kormikiairi estou formatando, e que também falam mais um pouco do laboratório.

Heródoto: Pensando no tema da cidade antiga, eu gostaria que a senhora falasse um pouco dos estudos sobre a cidade antiga. Quais são as perspectivas e as contribuições da História e da Arqueologia pra esse tema.

Florenzano: Quando começamos a estudar a história da cidade grega, eu entendo que estávamos numa posição tradicional, focalizando a cidade, a pólis e o urbanismo daquela cidade; então, a nossa referência mais importante do ponto de vista do urbanismo era Roland Martin, que é um grande arqueólogo francês que estudou o urbanismo grego de uma maneira muito sistemática e o Amos Rapoport, que é um grande arquiteto norte-americano, muito didático e também muito traduzido, que era útil pra nós. Ele fala da questão do ambiente construído e, no fundo, da cidade. Acho que nos quatro ou cinco primeiros anos, o Labeca concentrou-se no ambiente construído dentro da cidade. Nós aprendemos muito com essas leituras, mas aí você começa a entrar na Arqueologia, no documento material e a reflexão vai ganhando outros contornos.

Começamos a perceber que aquele conceito de Cidade-Estado não atendia o documento material; esta que é a questão mais interessante. Depois de dez anos trabalhando com essa temática, eu posso dizer o seguinte: o documento textual guiou os estudos sobre a Antiguidade de uma forma muito insistente, muito incisiva e desse documento textual foram aproveitados elementos que atendiam à curiosidade e às necessidades de cada época. Então, na Renascença, fez-se uma leitura de Aristóteles, de Platão, daquilo que se tinha (o texto "Constituição de Atenas" foi encontrado só no século XIX), mas era aquilo que se tinha nesse momento. O que estava acontecendo na Europa? Não era a formação do EstadoNacional? Então, não era a necessidade que se tinha de procurar nos antigos um apoio, um suporte, um conhecimento melhor sobre os Estados?

A partir disso, o que se focaliza? A política. Por que a pólis foi traduzida como Cidade-Estado? Por que a nossa palavra política vem de pólis, não é? Eu acredito que, até a década de 1940 e 1950, valorizou-se o documento textual nesse aspecto. Se consideramos o Copenhagen Polis Center (ainda 
bem que é Copenhagen Polis Center e não Copenhagen City-State Center), o foco deles era a Cidade-Estado grega e, até hoje, muitas traduções falam em Cidade-Estado. E, como se diz em inglês, este termo é taken for granted, é assumido, sem críticas e ninguém vai mudar isso. Mas, para nós, esse é um viés que focaliza sobretudo a vida no urbano e a vida na política. No século XIX, novamente, a preocupação com questões políticas: novos Estados sendo criados no Ocidente, Estados imperiais, a democracia... E a história da antiga cidade grega recebe um tipo de atenção que focaliza estes aspectos.

Hoje, inicialmente a Arqueologia está muito mais valorizada e trouxe contribuições diferentes e depois a problemática mais "bicuda", digamos assim, não é mais o Estado, mas essa porção de pessoas mudando de lugar, não é? Você pensa, estando na Europa e aqui no Brasil, vemos na televisão aqueles barcos chegando em movimento contínuo no Mediterrâneo; agora, essa crise na Venezuela com o pessoal saindo, migrando e quantos outros grandes movimentos populacionais não ocorreram na nossa história? Então, hoje o que nos interessa? Os gregos indo de um lado para o outro e a Grécia, não a Grécia da cidade, mas a Grécia das redes, dos networks e eu acho que a contribuição da Arqueologia nisso foi fundamental.

Por isso, a pesquisa que eu gostaria de fazer, mas que eu dei para o Guilherme Moerbeck realizar como pós-doutorando do Labeca é justamente, como que a história da Grécia passou da história da cidade para a história do Mediterrâneo. Pensemos nos textos antigos: o Platão não falava que os gregos eram como os sapos e as formigas na beira de uma lagoa? Significa que ignoramos (não demos suficiente destaque) a esse lado dos gregos para, ao invés, valorizar a cidade, a cidade e o Estado, chamando aqueles núcleos populacionais, as póleis, de Cidades-Estado. Acho que esse deslocamento de interesse no que toca o mundo grego, é a Arqueologia que vem promovendo, a começar pela grande Escola de Cambridge, com o Prof. Anthony Snodgrass que formou muitos arqueólogos e historiadores muito competentes como Jonathan Hall, Catherine Morgan, Carla Antonaccio, Suzan Alcock.

Penso, pois, que tenha sido a Arqueologia que, a partir da Segunda Guerra Mundial quando começam sistematicamente os surveys, --porque escavar monograficamente, um único sítio, é caro e os resultados, às vezes, não compensam o custo - como dizia, os surveys que são muito mais baratos, a trazer uma contribuição fundamental para compreender a intensa mobilidade dos gregos. Estes, os gregos, tinham como fronteiras espaços fluidos e abertos que podem ser vistos como frons como diziam os latinos. Frons o que é? É aquela área onde você quer chegar, e esse frons de fronteira nem sempre era no muro da cidade, aquele núcleo urbano fortificando, a 
fronteira não estava ali para os gregos. No século XIX, buscava-se ver cada cidade com seu muro, mas ali não era a fronteira das póleis, a fronteira era muito além e era uma fronteira que andava para frente e depois voltava, que fazia com que os gregos conseguissem interagir com muita gente que não era grega. Isso é fascinante!

Eu respeito demais um grande arqueólogo israelense, o Irad Malkin, que sistematizou o estudo das redes; e, com isso, percebemos que Atenas não era apenas Atenas, e não era só aquele Império que em uma época reduzida dominou o Egeu. As redes, as filias entre as póleis; quer dizer, entre os gregos existiam muitas redes sobrepostas: os dórios, os aqueus, as redes de mulheres, de religião... São redes que se sobrepõem e se movimentam permanentemente no mundo grego. Por que estamos falando só dos gregos e não de tanta gente que entrou em contato com os gregos? Eu fico pensando, há os fenícios que constituiram uma civilização extraordinária; eles entre tantos outros que também mantinham contato com os gregos. Eu falo que os gregos inventaram a moeda, mas a moeda é uma herança do Oriente Médio, daquela região, Anatólia, Mesopotâmia. Todo o sistema, não propriamente monetário, mas de peso, de medidas.

Então, por que hoje falamos dos gregos? Porque, eu acho, eles tiveram uma criatividade incrível de absorver muita coisa de outros povos, recebendo essa influência, mas sem perder os traços que eram próprios deles. Como dizia Heródoto: "a língua, a religião e o modo de vida", o Heródoto da sua revista. É uma delícia estudar isso, eu tenho que agradecer porque eu tive essa oportunidade, que a USP me deu e para a qual tive apoio da FAPESP; quem outro iria pagar um salário para ficar estudando isso? Pense bem! Com tantos problemas que enfrentamos hoje em dia! Mas entendo que esse tipo de estudo foi reconhecido pela USP e pela Fapesp porque, no fundo, traz uma contribuição muito grande para o espírito humano, para o nosso país.

Heródoto: Tem até algumas questões aqui que vamos discutir um pouco, sobre pensar a nossa cidade a partir dessas cidades antigas, dessas referências...

Florenzano: Fizemos, no Labeca, aquelas maquetes digitais, que estão disponíveis no site; são várias. Algumas até com formato de jogo, como o porto grego. Está lá também a maquete dos santuários, a de uma cidade grega, a de uma casa grega. Quando vemos as crianças pequeninhas olhando e comparando, você está dando uma contribuição, mostrando que você cria a partir do estudo do outro, você constrói sua identidade. Os próprios gregos, eu tenho essa sensação, também, eles viam os outros e foram consolidando a identidade própria. 
No nosso caso, é uma vantagem trabalhar em um museu. As crianças, primeiro ficam alucinadas, não só com as maquetes digitais, mas na exposição que a professora Elaine montou, com a maquete física que eles podiam pôr a mão, podiam sentir, podiam olhar. Comparar uma casa grega, de dois mil anos atrás, com a casa deles. Os caminhos dentro da cidade, como eram, as roupas. Penso que à medida que você tem possibilidade de comparar, você vai construindo sua própria identidade e percebendo como você é.

Conhecer os gregos não é aquela coisa, "ah, somos iguais a eles", não somos iguais a eles, justamente. "Ah, eles também tinham uma moeda redondinha de metal"; mas, a moeda para eles tinha muitos outros significados, e é um erro atribuirmos à moeda antiga da Grécia, ou mesmo à de Roma, o significado que ela tem para nós hoje, em uma economia de mercado, despersonalizada e assim por diante. Então, o estudo do outro e você poder comparar identificando as diferenças é o que nos torna cidadãos, é o que nos faz tomar consciência do que somos ou do que queremos ser, é o que constrói a nossa identidade.

Heródoto: A senhora fala um pouco sobre essas mudanças na compreensão da cidade e eu sempre me lembro que quando a gente estuda o mundo antigo, Grécia sobretudo, tem algumas cidades que vêm à mente e geralmente essas cidades são apresentadas como se fossem a Grécia como um todo. Então, tem Atenas e todo o debate agora recente descontruindo essa perspectiva do atenocentrismo. Eu gostaria que a senhora comentasse um pouco sobre esse processo da variedade da cidade no mundo antigo.

Florenzano: Então, esse é um tópos que não nos abandona. Atenas e Esparta em primeiríssimo lugar. Atenas e Esparta, e depois, aparece muitas vezes Tebas, aparece Corinto. Em qualquer manual didático, você quer falar do teatro grego que está consagrado nas fontes textuais, você tem que falar em Tebas. Você quer falar de Troia porque lemos os textos que falam da Guerra de Troia e aquela coisa toda. Homero, Hesíodo, o próprio Heródoto. Bem, Heródoto é aquele que é o grande, o que abre muitas portas para outras civilizações. Mas, se você pega um texto que permaneceu e que permanece até hoje, que é o do Tucídides, ali é Esparta e Atenas, apesar de ele falar de muitas outras cidades. É esse o foco que foi dado.

Então, em qualquer manual, é uma coisa inacreditável, sobretudo em português, o foco é Atenas e Esparta. Acho que os manuais de escola europeus já estão fugindo muito disso, mas os brasileiros, qualquer manual de escola, é insuportável essa história de só Atenas e Esparta e assim por diante. É um ponto de reflexão muito grande: eu acho que é a Arqueologia 
que está permitindo essa desconstrução também, que está permitindo uma nova leitura, uma releitura dos textos e "pescar" nos textos outras coisas que antes não queríamos ver. Eu acho que a Arqueologia tem uma contribuição muito grande.

Bem, em primeiro lugar, por que Atenas? É uma coisa que eu penso muito. Porque você pode falar "ah, o atenocentrismo é do século XIX", não é, não é do século XIX, ele vem desde antes.

Heródoto: Desde a Antiguidade.

Florenzano: Ele vem desde a Antiguidade. Por quê? A minha ideia, que é muito particular, eu não escrevi, não é meu tema, enfim. Depois você lê o Canfora; ${ }^{10}$ podemos também ler aquele artigo sobre atenocentrismo que você o Fábio que escreveram. ${ }^{11}$ Bem, a minha ideia particular é que os atenienses, eles mesmos, criaram uma reflexão sobre si. E eu acho que foi isso que atraiu os romanos; essa reflexão que eles produziram sobre a pólis deles deu espaço para outros. Por exemplo, Aristóteles não era ateniense. Atenas foi uma cidade especial, excepcional, que abriu espaço para uma reflexão sobre eles próprios. E foi isso que causou tanto interesse. Adriano ficou "vidrado" em Atenas, Cícero foi morar lá.

Eu fico pensando que talvez tenha sido isso que fez com que eles, inclusive, preservassem os textos produzidos ali, que foram muito melhor preservados do que outros textos produzidos na Ásia Menor ou mesmo no Ocidente mediterrânico. Há, por exemplo, o Timeu, que praticamente sumiu, que ficou preservado no Políbio, no Diodor Sículo. Por que que os próprios antigos preservaram obras grandes? E, no fundo, você vê a constituição que sobrou do Aristóteles? Dizem que a escola dele escreveu mais de cem constituições. Sobrou a de Atenas que só foi encontrada no século XIX. E as outras? Fragmentos em vários outros textos. Então, os próprios antigos acabaram preservando o que era de Atenas. Isso nos faz pensar. Eu acho que o Canfora resolve um pouco falando muito sobre a democracia. Parece-me que é um ponto de reflexão muito interessante e que os estudiosos deveriam enfrentar de peito aberto. Não basta só desconstruir, porque existe uma coisa ali que merece ser investigada.

Heródoto: E pensando nisso também, gostaria que a senhora falasse um pouco da variedade que eu vi já em muitas comunicações do Labeca, apresentações do laboratório, esse repertório de cidades.

\footnotetext{
${ }^{10}$ Luciano Canfora. Il mondo di Atene. Roma, Bari: Editori Laterza, 2012.

${ }^{11}$ Gilberto da S. Francisco; Fábio A. Morales. 'Desvelando o Atenocentrismo.' Revista de Culta e Extensão USP, vol. 14, p. 67-79.
} 
Florenzano: Então, por exemplo, fala-se a "ah, Atenas inventou a democracia grega". Se formos olhar muitas outras cidades, muito importantes na rede de cidades gregas, encontraremos muitos exemplos: apenas no sul da Itália há Tarento, Lócris, a própria Nápoles, Régio, Crotona, cidade importantíssima que abrigou Pitágoras; Eleia, berço de filósofos, Túrio. Na Sicília, Siracusa era quase tão grande quanto Atenas; até, em alguns momentos, foi mais poderosa que Atenas. Subiu pelo Adriático conquistando cidades e pode-se dizer que foi tão poderosa quanto Corinto que a fundou. Na Sicília mesmo, quantas outras cidades gregas importantes como Agrigento e Selinunte, que foram cidades enormes com campos plantados e em contato direto com fenícios e com outros gregos. E quem se lembra que Marselha foi uma fundação grega?

E Argos, sobre a qual se fala pouquíssimo a não ser quando se fala das tragédias. Sem falar nas do Mar Negro: Ístria, Ólbia, Heraclea, Apolônia. E Mileto que fundou tantas destas colônias nessa região? O que se diz sobre Mileto? Apenas a planta urbana desde que o Von Gerkan, em 1924, foi até lá e fez aquele estudo urbanístico. E, só de passagem, aquela planta é da cidade romana, e não da cidade grega. Mas, Mileto era uma potência. Heródoto disse que ela tinha um colar de pérolas no Mar Negro de tantas colônias, cada colônia era uma pérola. Então, são cidades poderosas. Foceia, lá no norte do Egeu, que foi fundar Marselha e Eleia, do outro lado do Mediterrâneo. Quem lembra dessas cidades?

Então, são cidades que tiveram papel fundamental na construção do helenismo e que passaram por períodos de governo democrático, as vezes mais longos, as vezes mais curtos. Como em Atenas, tirania, democracia, oligarquia, se revezavam como forma de poder em todas elas.

Hoje, muitas dessas cidades são escavadas sistematicamente trazendo contribuição importante para a compreensão do helenismo. Tasos, por exemplo, que foi muito escavada pela Escola Francesa de Atenas: sabemos do poder que tinha, da ocupação e domínio de terras no continente; Olinto muito conhecida pela grande área habitacional ali escavada e tantas outras.... Como vamos conhecer o que foram os gregos, o que foi o helenismo estudando apenas Atenas e Esparta? Como se Atenas e Esparta, sozinhas, tivessem criado essa helenidade? Eu acho que o mundo grego antigo foi um mundo muito grande e que "pipocava" por todo o litoral do Mediterrâneo.

Se pensarmos, por exemplo, em Náucratis, no Egito, uma colônia fundada desde o século VIII, com permissão do faraó. Acho que são doze cidades 
gregas que participaram da fundação e que mantinham a cidade como um empório neutro em pleno delta faraônico. Se pensarmos em Cirene, no norte da África, ali fundada por gregos e que imediatamente rodeou-se por mais quatro cidades em volta, todas gregas, dividindo os espaços com os cartagineses. Então, o quadro que aparece é um mar que os gregos dividiam em equilíbrio com os fenícios: às vezes, brigavam e, às vezes, andavam juntos, porque eles andavam juntos. Tanto andavam juntos que quem criou o alfabeto usado pelos gregos foram os fenícios.

Por que os fenícios não receberam a mesma atenção que os gregos? A tese de Jonathan Hall, é que isso ocorreu porque o preconceito europeu não permitiu. Porque eles eram ali do Médio Oriente; e, a rigor, misturados com judeus, aquela coisa que o europeu mantinha como preconceito. Essa é a tese do Jonathan Hall. Naqueles barcos do século IX e VIII, os eginetas, os calcídicos circulavam pelo Mediterrâneo com os fenícios, conforme mostra Alfonso Mele no livro Prexis ed emporie (esse é um grande pesquisador que escreve em italiano e então é pouco lido pela academia...). Este era um mundo de redes. Eu acho que a teoria das redes dá mais conta do que o termo Cidade-Estado; dá muita conta de muita coisa, e eu acho que a contribuição da Arqueologia nesse sentido é fundamental. E acho que por isso, o Labeca partiu para estudos variados, abrangendo cidades a Ocidente e a Oriente da Península Balcânica. Porque procuramos conhecer melhor a sociedade grega como um todo.

Heródoto: Para pensar na complexidade desses conceitos, geralmente a gente observa que o que é aplicado não responde à complexidade desses avanços que a senhora estava aqui mostrando para a gente. E eu me lembro do Kostas Vlassopoulos dizendo que a pólis, que geralmente é um conceito que é usado para explicar de forma uniforme o mundo grego, ela não é suficiente; e ele vai pensar dentro dessa lógica das redes e até uma compreensão em determinados períodos do mundo grego como uma periferia de um processo que vem sendo desenvolvido pelos persas. Eu gostaria que a senhora falasse um pouco sobre esses conceitos: pólis, Cidade-Estado, e sobretudo de colônia, e a noção de periferia, que é tão importante aqui porque, na nossa situação, há também essa questão de uma academia que se organiza numa periferia.

Florenzano: Bom, eu acho que sobre pólis e sobre Cidade-Estado falamos já alguma coisa. Acho que vale a pena destacar a questão do termo colônia. Este termo vem do latim: eram aquelas colônias latinas que os romanos fundavam depois de conquistar e conseguir o apoio de alguma região. Termo vinculado à agricultara, a "plantar", "colher". Na historiografia moderna, o termo foi e é empregado para caracterizar uma dominação europeia sobre outros territórios. Então, as colônias africanas e as colônias 
na América, na Ásia também (a Índia no império britânico e assim por diante). Ele foi empregado igualmente para definir as fundações gregas do século VIII no Mediterrâneo. Você sabe, em 1998, o Robin Osborne escreveu um artigo que provocou algum impacto dizendo que colônia é um termo equivocado para definir as fundações gregas de época arcaica já que tem conotações modernas que não correspondem ao mundo grego antigo. A partir desse texto do Osborne (que, na verdade aprofunda uma idéia expressa anteriormente pelo grande historiador Moses Finley) teve inicio um grande debate acadêmico. Os franceses, por exemplo, ficaram aflitos e imediatamente começaram a pensar em diáspora, em expansão, sempre pensando movimentos a partir de uma base grega única em diásporas ou em expansão pelo Mediterrâneo. Recentemente, no contexto do Laboratório coordenado pelo Prof. Guarinello (o Leir-MA) também tivemos uma discussão sobre essa questão no tocante aos gregos no Adriático. O termo colônia tem sido muito questionado e se chega mesmo à conclusão que se você usa o termo colônia você está usando aquela ideia do Wallerstein, de um centro e de uma periferia: existe um centro e este irradia para uma periferia. A teoria das redes propõe uma outra perspectiva. Existem vários knots, vários núcleos e eles irradiam a partir de outros núcleos e viram um mar, digamos assim, de redes sobrepostas, de linhas de contato e de mobilidades sobrepostas.

Então, por exemplo, sobre a história dos persas, isso é uma coisa que eu muito me surpreendi, naquele semestre em que estive na Brown University como professora visitante (1994), o Prof. Ross Holloway chegou para mim e falou "olha, você nunca percebeu que aquelas cerimônias, aquelas procissões nos frisos persas, elas são iguaizinhas àquela procissão que se vê no friso do Pártenon?". E eu pensei “Nossa! Vai ver que é mesmo, não é?" Então, segundo ele, muitos artesãos gregos eram contratados pelos persas. Ou será que os gregos adaptaram o que viam entre os persas?

Mas, porque no capítulo três do Heródoto tem a famosa discussão na corte persa sobre qual é o melhor governo? Por que? Porque os persas estão presentes ali com o tipo de governo deles, e que os atenienses foram refletir sobre isso e depois uma discussão que é retomada pelo Políbio, não é mesmo? Então, os persas fazem parte dessa rede que o Vlassopoulos está falando, agora eu não sei se os persas eram o centro. Só que hoje, não estamos falando dos persas, não é? Estamos aqui no Brasil falando dos persas? É essa questão que se tem de enfrentar de peito aberto.

Como falar em colônia em uma rede de contatos como esta criada no Mediterrâneo antigo? Colônia para nós - brasileiros ao menos- já vem com o sentido de "subalterno", de domínio. E isto, de fato, não correspondia ao que hoje chamamos de colônia na Grécia antiga. Mas, então, que outro 
conceito podemos usar? Diáspora serve? Não serve. Expansão serve? Não serve também. Domínio? Império? Que palavra vamos usar dentro do nosso vocabulário? E isso foi o Emanuele Greco ${ }^{12}$ que me fez pensar quando esteve aqui no Brasil em um simpósio organizado pelo Labeca em 2013. Ele falou: "então, não querem usar colônia? Pra nós italianos tanto faz, não faz a menor diferença. Se para vocês incomoda, usem um termo grego". E, no Labeca, nós começamos a usar o termo grego, apoikismo. Temos procurado usar apoikia e temos evitado usar "colônia"; evitamos também usar Cidade-Estado. Então, como eu falei, você vai ver os gregos no Adriático a partir de qual ponto de vista? Você tem que ter um ponto de apoio, de referência. Centro e periferia podem servir em algumas ocasiões? Pode servir, mas adaptado. E todos os termos que usamos, mesmo se usarmos "colônia", temos que fazer um uso crítico.

Nos Cadernos do LEPAARQ, no último número, o 29, há um dossiê sobre colonização. Lá, tem um artigo do Airton Pollini que abre portas para reflexão também. A professora Elaine, na livre docência dela, também tratou em um capítulo sobre a questão do termo: o que usar? Se usa colonização ou se não usa colonização? E ficamos "usa; não usa mais". No Labeca, nos cansamos um pouco, porque ficamos perdendo tempo em uma questão retórica. Não é nem teórica, é uma questão de nomenclatura. Uma questão de nomenclatura, e sabemos que se poderia usar colonização de forma crítica com uma explicitação do sentido que queremos dar a esse temo. Só que esbarramos nas questões dos manuais. Então, nos manuais, se você puser colonização, o professor que dá aula na quinta série vai entender como colonização no sentido de Portugal colonizando o Brasil.

Por isso, temos procurado usar nos nossos textos, quando traduzimos, em nossos projetos, as palavras apoikismo e apoikia; usamos pólis e, às vezes, cidade, mas não Cidade-Estado. É um debate e eu estou aberta ao debate. Quando eu ofereci o meu texto sobre Siracusa, ao dossiê dos Cadernos do LEPAARQ sobre "colonização", fui criticada por não usar colonização, por não usar colônia. Meu argumento de defesa foi que eu achava que estava dando alguma contribuição para a área de estudos clássicos no Brasil, e que os que me lessem, estudantes, professores e pesquisadores talvez se sentissem provocados a ir buscar o debate sobre os termos anacrônicos que empregamos em nossos trabalhos...

Temos um glossário no Labeca onde, inclusive, aportuguesamos a apoikia. Porque até já está consagrado em português a palavra "cleruquia", $\operatorname{com} q u$, cleruquia. Essas são as colônias. Colônias do "império" ateniense, as

\footnotetext{
${ }^{12}$ Emanuele Greco, Professor da Università L'Orientale di Napoli, e ex-diretor da Escola Arqueológica Italiana de Atenas.
} 
colônias militares cujo nome vem de kleros e de oikos. Então, por que eu não posso usar apoikia? Só que agora tem essa nova ortografia, na qual o $q$ virou $k$. Então eu pensei: vamos usar apoikia em português e apoikias no plural. Pólis também, não sei se você sabe, está dicionarizado e plural é pólis. Mas, as pessoas têm uma volúpia com o vocabulário, gostam de falar póleis, porque é bonito, fica parecendo que você é mais culto, mais erudito. Então, eu deixo meus alunos. Eles gostam de colocar nas dissertações, nas teses, pólis e póleis. Então, o glossário Labeca dá essa abertura.

Heródoto: Acho isso interessante porque já, inclusive, desenvolve um pouco da questão do o que é pensar cidade antiga no Brasil. O que a gente enfrenta aqui no Brasil.

Florenzano: Que difícil, não? Que difícil. Eu lembro que eu fiz meu mestrado, acho que com uma publicação de 1911, e depois o professor Ulpiano $^{13}$ comprou para o museu um livro que era de 1976, que era o mais recente, do Colin M. Kraay. Depois, os outros manuais de Numismática que eu tinha eram do século XIX e eu fiz o meu mestrado com isso. Não tinha bolsa, não tinha dinheiro para nada. De lá para cá, o mundo acadêmico mudou consideravelmente e graças aos esforços de todos os envolvidos os recursos vem chegando. Ainda que continue difícil se conseguir recursos para estas pesquisas, uma vez que nunca são consideradas "prioritárias".

Em algumas fases, nós fomos muito beneficiados, com recursos FAPESP, que sempre esteve muito aberta para o apoio. Mas, esta é uma área que envolve o conhecimento de línguas antigas como o grego e o latim e a formação exigida para tratar com a antiguidade do Mediterrâneo é muito mais longa do que, por exemplo, aquela de um estudante que pretende se formar em Arqueologia Brasileira. A formação é muito mais longa, porque além de demandar o aprendizado de línguas antigas como dissemos, implica na leitura de fontes primárias e de uma bibliografia que praticamente vêm desde o Renascimento, dependendo do tema que você quer trabalhar.

Em Ciências Humanas, diferentemente das Ciências Exatas, o diálogo com quem veio antes de você tem que ser permanente. Você não pode escrever sobre a democracia e ignorar os textos clássicos do século XIX e nem Aristóteles, para citar apenas uma fonte primária. Não pode escrever sobre a cidade grega e ignorar Fustel de Coulanges, que escreveu no século XIX. Não dá. Então, é uma leitura, e uma leitura complicada. Você não pode falar sobre a cidade grega e ignorar todos os textos escritos por Jacob

${ }^{13}$ Ulpiano Toledo Bezerra de Meneses, Professor Titular (aposentado), FFLCH-USP. 
Burckhardt, não é? Há textos mais antigos ainda, datam da Renascença como os estudos de G. Budé e tantos outros que o aluno tem que conhecer se quiser elaborar uma reflexão sobre a antiguidade grega ou romana. Do contrário, você não escreve a história do passado. Assim, além da bibliografia, além das fontes, além das línguas, há falta de recursos.

Os norte-americanos, por exemplo, despejam recursos nessas áreas do conhecimento. Talvez dependam delas para a construção de sua identidade como potência mundial. Qualquer aluno de iniciação científica nos EUA que queira estudar a Antiguidade do Mediterrâneo já tem bolsa, vai para a Grécia, vai para Roma. Têm as escolas, a Escola Americana em Roma e aquela de Atenas, que dão apoio, que dão alojamento, que inserem os alunos nas escavações, para que tenham um aprendizado. Eu, por exemplo, meu treinamento de escavação, lá atrás, na década de 1970, onde foi? No México, na Amazônia. A dificuldade de participar de escavações na Europa eram então muito mais difíceis. Felizmente, hoje em dia, esta situação está muito melhorada. Primeiro, porque hoje temos a internet, pode-se baixar toneladas de PDF pela internet. Naquela época, nós não tínhamos nem máquina copiadora. Havia uma máquina Xerox na USP e ficávamos horas na fila para fazer cópia de textos que tínhamos que ler. Dependíamos de quem viajasse e nos trouxesse cópias de artigos e até de livros inteiros. Lembro que, em 1982, para o meu doutorado, eu passei quatro meses na Bélgica, e despachei por correio 40 quilos de xerox, para poder trabalhar no Brasil. E xerox que eu mesma fazia. Mudou muito, ainda bem...

Hoje, reafirmo, o que enfrentamos mais é a falta de recurso. Recurso pra viajar, porque também nos países você não pode chegar e escavar. Muitas vezes você tem que comprar autorizações, ou você tem que se inserir em um grupo de pesquisa no exterior e, por exemplo, se você quer fazer uma inserção em um grupo de pesquisa da Grécia, você tem que estar como você, Gilberto, filiado a uma Escola de Arqueologia, das que se instalaram na Grécia no século XIX ou início do XX. E você bem sabe qual foi o processo por que teve que passar para isso. E a Escola lhe abriga, mas não oferece recursos suficientes para o deslocamento do Brasil até a Grécia nem seu nem de seus alunos e para as demais atividades os recursos são escassos. Mesmo a Escola Francesa de Atenas para publicar os trabalhos por eles realizados enfrenta uma grande dificuldade em vista da falta de recursos. Eu vejo que ou se tem muitos recursos (como é o caso dos norteamericanos) que chegam com financiamento completo para expedições de escavação ou, realmente se tem muita dificuldade para empreender uma pesquisa que dependa de muito trabalho em campo. No fundo, nosso projeto em Israel não teve continuidade por conta disso. Porque 
precisávamos de uma maior inserção no meio acadêmico israelita e este dependia de maiores recursos. A Brown University acabou entrando em Apolônia; naturalmente ofereceram mais, e nós finalizamos nosso projeto e não demos o prosseguimento que eventualmente esperávamos.

Agora, o que não deixa a gente desanimar, é que muitas escavações foram feitas desde o século XIX, e muito material está guardado juntamente com a sua documentação de proveniência, nos magazines e nas reservas técnicas de muitos museus europeus; e, no meu caso, o das moedas, em muitos cabinet des médailles, gabinetes numismáticos. Ou, por exemplo, no caso da Itália, em muitas superintendências regionais de arqueologia, como eles chamam lá. Há muito material que não foi publicado e que não foi estudado. Se você for estudar, por exemplo, arqueologia mesopotâmica, há centenas de tabletes cuneiformes que não foram lidos e não foram publicados em vários dos Museus europeus.

Então, há material, há documento material, fonte primária; e dependemos de negociação para poder estudar. Eu acho que faltam recursos, mas faltam recursos na Europa também para esse tipo de estudo; e há caminhos que são, às vezes, complexos, burocráticos. Mas podemos conseguir muita coisa. Eu acho que essa é uma área que, ainda, tem muita coisa para fazer, pois há, repito, muitos catálogos publicados.

Por exemplo, no novo projeto do laboratório (Labeca), eu vou estudar a Calábria. Tem muita publicação de material arqueológico fundamental mas que não incluem estudos relacionais e/ou interpretativos. Muitos são simples catálogos. Há muitos surveys que foram publicados, mas as interpretações sobre eles não vão a fundo. Publica-se os dados, ensaia-se alguma interpretação. Aliás, essa é uma tendência da arqueologia contemporânea, estudar os catálogos, re-estudar catálogos, achados, diante dessa perspectiva nova da nossa mobilidade.

Heródoto: Parece que a crise força também a gente a pensar no que já foi escavado, no que já foi publicado, desenvolvido.

Florenzano: Exatamente. Então, eu não desanimo meus alunos, porque acho que tem muita coisa a ser feita. Uma vantagem estarmos na periferia, na "colônia", é que nós não estamos filiados à ortodoxia e ao jogo político de nenhum grupo. Eu posso criticar o texto do Robin Osborne, elogiar um outro texto de outro pesquisador sem entrar em uma engrenagem de política acadêmica específica. Eu posso dialogar com eles, aproveitar o que há de bom em cada um e misturar, criar. Eu acho que, no nosso laboratório, fizemos e continuamos fazendo muito isso: consideramos o que os ingleses dizem, o que os vários grupos italianos dizem, e se consegue criar alguma 
coisa nova aproveitando o material que eles nos fornecem, e acho que isso que é interessante, e esse diálogo tem provado isso. Quando veio o Emanuele Greco, ele falou "puxa, eu não tinha pensado nisso. É... mas essa autora que a senhora usou é uma tonta, e eu não a suporto!". Quer dizer, é do grupo contrário ao dele; mas ela tinha ideias e eu consegui usar. Então, eu acho que temos algumas vantagens nesse sentido.

Heródoto: Para finalizar, professora, eu gostaria de perguntar para a senhora sobre dois elementos relacionados aos resultados do laboratório, de todas essas reflexões ao longo desses últimos anos, que extrapolam o meio acadêmico: o primeiro é a exposição que o MAE apresentou até pouco tempo, "A Pólis: viver na cidade grega", como ela já terminou, eu acho que é possível até pensar no que foi a exposição, no tipo de recepção que ela teve. E também, os resultados do ponto de vista didático, extrapolando este mundo da academia.

Florenzano: Então, o fato de nós estarmos sediados num museu, nos abriu essa possibilidade de fazer uma divulgação científica de alto nível, porque nos permitiu montar um site que propõe a divulgação em várias perspectivas. Como eu já mencionei, temos as várias maquetes digitais, o DVD que produzimos sobre Siracusa (26 minutos) e que vem acompanhado de um livreto de apoio ao professor. ${ }^{14}$ Outra coisa, além das maquetes digitais de espaços específicos (o porto, a casa, a cidade, o santuário), tem ainda aqueles dois filmezinhos que fizemos em 2007, quando fomos para a Sicília, e que são de acesso livre: a pessoa entra no site e pode rodar, pode brincar no videogame que é o porto e são produtos elaborados pelo Labeca. ${ }^{15}$

Além de ter o produto didático do filme sobre Siracusa com o livreto para o professor, tem outro livreto fizemos sobre a cidade antiga em imagens, é tipo um glossário ilustrado. Contratamos um desenhista que criou vários espaços de uma cidade grega e, inclusive, partes que não estão dentro do centro urbano, mas fora dele. E, com esses desenhos, pudemos explicar cada espaço (o livreto também está disponibilizado no site do Labeca).

Agora, a exposição foi bastante gratificante, porque ela coroou nosso trabalho; foi muito visitada e os educadores do museu fizeram um programa especial de recebimento de professores secundários e um treinamento especial com o material didático produzido pela professora Elaine, curadora científica da exposição. Ela escreveu um texto, que eu não tenho certeza se já foi disponibilizado no site, com imagens e que era

${ }^{14}$ Silvio L. Cordeiro. 'Siracusa - Cidade Antiga.' Revista do Museu de Arqueologia e Etnologia da USP, Suplemento 12, p. 79-80, 2011.

${ }^{15} \mathrm{http}: / /$ labeca.mae.usp.br/pt-br/professores/ 
trabalhado com os professores. E, a partir deste treinamento, os professores retornavam para a sala de aula e explicavam para os alunos e, depois, os alunos vinham e visitavam a exposição. Havia fotografias que foram feitas, as crianças (desde pequenas até as do colegial, do ginásio) ficaram muito entusiasmadas, desfrutaram desta exposição. E, na exposição, também tinha uma das maquetes digitais que ficava disponível para eles poderem acessar. Essa foi uma experiência muito importante e interessante e que graças ao empenho da Profa. Elaine, inseriu definitivamente o Labeca como um Laboratório de Pesquisa em Museu, ligando a pesquisa ao acervo e fazendo o contato tão importante com a sociedade. Os alunos da USP também da Faculdade de Arquitetura e Urbanismo tiveram uma visita guiada à exposição, assim como os alunos de graduação, de uma disciplina optativa que ministro há anos também puderam aproveitar $o$ conhecimento ali exposto de forma mais accessível. Disciplina optativa que você fez, Gilberto, há um tempo atrás...

Heródoto: História e Arqueologia da Grécia Clássica e Helenística.

Florenzano: É, ainda é a mesma disciplina, mas eu mudo todo ano. E, no ano passado, 2017, no primeiro semestre, eu peguei os alunos e falei: "vocês vão tirar a manhã inteira, vão visitar a exposição". Eu tinha dado os textos para eles lerem, eles visitaram a exposição e, depois, eles apresentaram uma avaliação crítica: o que faltou, o que que não faltou. Mas, a maior parte estava entusiasmada, então os próprios alunos da universidade demonstraram a importância de uma exposição daquele tipo para o aprendizado. Eu me senti muito bem, e eu achei que a professora Elaine estava de parabéns porque ela ficou um semestre inteiro planejando a exposição junto com os educadores, com os museólogos, atividade que contou com o apoio incondicional do MAE.

Eu acho uma pena que, por falta de recursos, o nosso banco de dados (o Nausítoo - que é um fundador arquetípico de cidades na Grécia) não está disponibilizado. Recebemos sempre muitos pedidos de imagens e de acesso ao Nausítoo, mas eu não tenho podido responder a todos; porque, sozinha, não tenho fôlego, e porque o banco precisa ser atualizado para poder ficar disponível para um público geral. Mas, eu recebo pedidos de professores da Universidade do Amazonas, daquele pessoal de São Luís do Maranhão, do pessoal do Rio de Janeiro... todo mundo pede imagens e pede acesso ao banco de dados e tem até interesse de consultas de algumas pessoas no exterior. E por quê? Porque está tudo reunido ali.

Mesmo na Itália, não é fácil encontrar tudo reunido. Tudo bem, você acessa pela internet, mas a qualidade da imagem não é boa e nós podemos oferecer imagem em 300 dpis. Fotos que nós mesmos fizemos ou fotos que 
a escanemos, sempre com a marca d'água do laboratório, por causa dos direitos de imagem, aquela complicação toda. Mas, essa é uma coisa que nesse novo projeto da FAPESP, contratamos uma consultoria de informática para desenvolver o banco de dados, para podermos atualizar essa parte de divulgação.

Então, é um Laboratório que trabalha nos vários níveis, tem uma divulgação científica, estamos na publicação do quinto livro. Acho que está bom, não é? Cinco livros em 10 anos! Temos registro de mais de setenta pesquisas, e temos esses produtos que são produtos típicos em um Museu. Por outro lado, traduzimos muitos textos que foram disponibilizados pelo site: capítulos de livros, traduções caseiras que fizemos, mas que servem como material didático. Temos um mapa dos acessos, e por isso sabemos quem está acessando o site e de onde, que países e, às vezes, eu olho lá e falo: "nossa, alguém na África do Sul acessou, alguém na Austrália". Há algumas coisas que poderíamos desenvolver mais se tivéssemos mais recursos e mais possibilidades de envolver mais alunos com bolsas. Mas, eu acho que temos conseguido fazer bastante coisa.

Heródoto: Claro! Muito bem, muito obrigado, professora. Agradeço muito pela presença.

Florenzano: Imagina, eu que agradeço. Eu gosto dessas coisas, eu acho que é importante para nossa área de Arqueologia Clássica e de mundo clássico e o mundo grego. Eu acho que é muito importante e uma oportunidade. Muito Obrigada!

Heródoto: Muito obrigado, e nós encerramos aqui. 